\title{
Singuagens
}

\section{EDUCAÇÃO LINGUÍSTICA NA EDUCAÇÃO INCLUSIVA}

\author{
Ivan Vale de Sousa
}

\begin{abstract}
RESUMO: Os padrões ideacionais da Língua são propósitos inclusivos dos falantes às experiências de comunicação. Nesse sentido, são objetivos deste trabalho: refletir acerca da educação linguística, da língua em uso e nas interações entre os sujeitos; discutir a importância da educação linguística com as práticas de educação inclusiva em contextos de ensino e, por fim, apresentar os recursos tecnológicos como possibilidades de inserção dos sujeitos com deficiências nas ações metodológicas de aprendizagem. Este trabalho, de natureza reflexiva, parte da aproximação entre a educação linguística no contexto da inclusão. Dessa forma, as incursões apresentadas projetam-se em propostas de valorização das habilidades dos sujeitos no contexto ético da inclusão.
\end{abstract}

PALAVRAS-CHAVE: Língua. Educação linguística. Educação inclusiva. Recursos tecnológicos.

ABSTRACT: The ideational patterns of the language are inclusive purposes of the speakers to the communication experiences. In this sense, the objectives of this work are: to reflect on the linguistic education, the language in use and the interactions among the subjects; to discuss the importance of linguistic education with the practices of inclusive education in teaching contexts and, finally, to present technological resources as possibilities of insertion of subjects with disabilities in the methodological actions of learning. This work, of a reflexive nature, is part of the approximation between linguistic education in the context of inclusion. In this way, the incursions presented are projected in proposals for valuing the subjects' abilities in the ethical context of inclusion.

KEYWORDS: Language. Linguistic education. Inclusive education. Technological resources.

\section{INTRODUÇÃO}

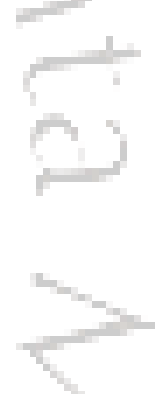

Somos identificados pela Língua que falamos, porque razão da nossa identidade está relacionada com língua em uso, isto é, as habilidades linguageiras. Sabemos que a Língua se realiza de muitas maneiras: na modalidade falada, escrita e gestual, além de representar nossa forma de interação com as práticas de linguagem.

As reflexões dos propósitos acerca da Língua como uma das funções identitárias dos sujeitos reafirmam-se mediante os contextos de uso que propiciam dinamização do processo de interação humana. Por um lado cada comunidade apresenta sua identidade, isto é, a Língua que materializa os acontecimentos e necessidades dos sujeitos e, por outro, a Sociolinguística, ciência que investiga a compreensão como os falantes de grupos e comunidades sociais enxergam as transformações na ação de interagir, mantém as funções características que perpetuam as concepções linguísticas e culturais nas formas comunicativas, visto que cada Língua apresenta suas variantes e peculiaridades a partir das experiências dos falantes. 


\section{S Linguagens}

O interesse em abordar as concepções de Educação Linguística na Educação Inclusiva surgiu da necessidade de ampliar as abordagens de ensino de Língua Materna no contexto da escola inclusiva como proposta de acessibilidade ao saber. Além disso, faz-se necessário considerar o contexto sociocultural dos sujeitos ao uso da linguística na apresentação aos indivíduos com necessidades educativas especiais.

Entender, por exemplo, como determinadas construções e variantes na língua acontecem foram as razões que me fizeram reiterar a relevância dos objetivos inseridos neste trabalho, porque as variantes que o Português Brasileiro recepciona são muitas. E assim como nossa Língua Materna, todas as línguas comportam variações que são adequadas pelos falantes aos contextos de uso e, de maneira enfática, admito que: toda língua só é preservada quando é entendida e usada por seus usuários.

As reflexões neste trabalho estão divididas em dois tópicos discursivos, a saber: apresentam-se no primeiro, algumas excursões relacionadas à educação linguística no contexto da Educação Inclusiva reafirmando que cada falante apresenta uma maneira própria e singular de enxergar, analisar e descrever a Língua. No segundo, as discussões mantêm estreita relação com o uso das tecnologias digitais capazes de amenizar as barreiras sociais e linguísticas no contexto formal da escola inclusiva permitindo aos falantes interagirem à sua maneira, considerando seus múltiplos contextos.

\section{EDUCAÇÃO LINGUÍSTICA INCLUSIVA: DESAFIOS E POSSIBILIDADES}

A releitura efetivada nos estudos referentes às capacidades de linguagem é demonstrada a partir da experiência de sujeitos leitores e escritores na concepção acessível do conhecimento. Todos nós apresentamos uma experiência principiante com os aspectos linguísticos, interativos e de compreensão dos propósitos no ensino de Língua Materna, porque são as nossas vivências que demonstram um pouco de cada um de nós na produção do conhecimento que, muitas vezes, precisamos reivindicar os espaços de produção dos nossos discursos tanto de maneira escrita quanto oralmente.

Quando consideramos o contexto linguístico em que cada sujeito está inserido, contextualizamos as oportunidades de articulação dos saberes internalizados com as situações sociais e cotidianas às quais somos expostos. Uma vez que estimulamos e difundimos outros e 


\section{S Linguagens}

novos conhecimentos que podem ser produzidos nos contextos da linguagem a qual somos submetidos. Assim, refletir os propósitos da educação linguística na concepção das propostas acessíveis e inclusivas de outras ciências e conhecimentos significa enxergar a efetivação da linguagem inserida nas ações da interdisciplinaridade.

A construção de uma proposta linguística não se resume na valorização de determinadas maneiras de interação social e regionalista da Língua Materna, mas, coaduna-se no respeito às condiçôes e aos saberes que o outro apresenta, não desconsiderando a valorização do ritmo de cada sujeito para que se sinta bem-vindo no processo intelectual de ensinar e aprender e, principalmente, na socialização do conhecimento, visto que não existe uma única e correta maneira de falar, mas diversas formas de realização da Língua adequadas às experiências dos falantes e isso auxilia no entendimento das noções linguísticas que, muitas vezes, são discutidas a partir de um único prisma sem considerar a dinâmica escolar.

Refletir sobre a educação linguística na concepção da inclusão e das metodologias desenvolvidas na instituição escolar e fora dela é, pois, percorrer um caminho caracterizado pela riqueza e pela experiência de falares e da interação entre os sujeitos, além disso, tem-se a noção de revisitar e reconstruir trajetos percorridos e permeados por desafios de ensinar e por perspectivas a serem almejadas. Logo, educar linguisticamente coaduna-se na valorização dos propósitos e sentidos que os textos assumem socialmente na vida das pessoas o que tangencia ao processo reflexivo de compreensão da Língua sua aplicabilidade, primeiramente, na promoção do ser humano e nunca nas suas limitações.

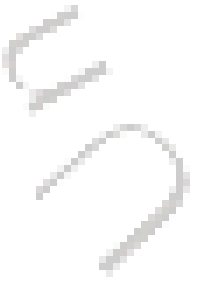

Ela se justifica na medida em que mostra haver regras gerais que valem para fenômenos ou fatos que ultrapassam o âmbito da frase: regras que dominam extensões de várias ou muitas frases. Um texto pode ultrapassar e até violar regras da gramática de frase, mas isto é sempre feito por alguma motivação interna, sendo assim um nível autônomo de investigação (MARCUSCHI, 2012, p. 16).

Tanto na efetivação quanto no respeito às variedades linguísticas encontradas no espaço da sala de aula e fora dele, muitas são as formas de intervir no processo de ampliação das capacidades da linguagem que se espera dos sujeitos na interação, visto que todos nós sabemos reconhecer ou não um texto e, mais ainda, distinguirem quais são os elementos verbais e não verbais que mantêm relação de reciprocidade interlinguística entre os propósitos projetados na relação interpessoal e comunicacional.

Linguagens \& Cidadania, v. 19, jan./dez., 2017. 


\section{S Linguagens}

Todos nós trazemos um estilo de conhecimento que é nato e que se amplia a partir da interação entre outras maneiras de enxergarmos o outro, de vislumbrarmos suas necessidades cognitivas, afetivas, motoras e sociais, porque é na troca dos saberes que a imanência ao sistema linguístico é fortalecida na produção de novas formas de dizer, de ouvir e expressarse. A nossa relação com a linguística tem início no âmbito familiar que abarca outras sequências quando nos inserimos em diversos grupos, nos contextos sociais mediante os fatores linguísticos que são tomados como referências do nosso aprendizado, por isso, ensinar constitui-se de uma "proposta de ação e de reflexão das práticas pedagógicas que se concretizam na experiência da sala de aula que oferece as mesmas oportunidades de interação a partir do ensino adequado às situações comunicativas" (SOUSA, 2016, p. 08).

A educação linguística não desconsidera a Linguística Textual, visto que é mediante a utilização de textos que os propósitos sociais da Língua se realizam nos contextos formais de ensino e aprendizagem, já que eles formam um processo complexo de produção e de recepção dos sujeitos. Nesse sentido, não é possível imaginar uma Língua pura e homogênea que não tenha influência de culturas e povos diferentes, já a sentença linguística na concepção do ensino linguístico é algo dinâmico com suas combinações precisas para destacar os sentidos e os aspectos organizadores do processo de interação.

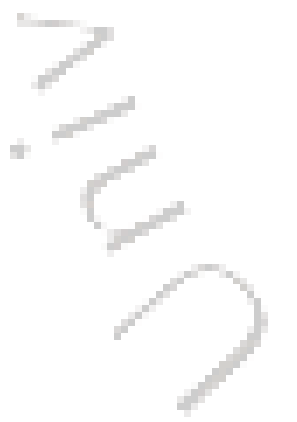

Toda língua comporta variações de duas ordens: em função do falante (ou, em termos de comunicação, do emissor) e em função do ouvinte (ou do receptor, e também das circunstâncias em que se produz a fala). À primeira ordem pertencem as variantes que se podem chamar dialetais em sentido amplo: variantes espaciais (dialetos geográficos), variantes de classe social (dialetos sociais ou diastráticos), variantes de grupos de idade (dialetos etários), variantes de sexo (dialetos masculino e feminino), assim como variantes de gerações (variantes diacrônicas). Na segunda ordem de variação incluem-se as variantes que, segundo recente sugestão, diremos de registro: variantes de graus de formalismo, variantes de modalidade (falada e escrita) e variantes de sintonia (ajustamento do emissor ao receptor). Tanto as variações da primeira ordem como as da segunda se superpõem e se entrecortam de diversas maneiras, do que resulta uma situação extremamente complexa, mesmo quando nos limitamos à observação da língua de um só indivíduo (RODRIGUES, 2012, p. 11-12).

Trabalhar a Língua como sistema dinâmico na escola é uma necessidade, o que não desconsidera métodos e análises que são realizados na compreensão da estruturação linguística. É preciso, pois, enxergar no espaço de escolarização das aprendizagens uma oportunidade de destacar todos os problemas que se pensam da Língua: destacar como as 


\section{S Linguagens}

variantes se adequam aos contextos e como representam um processo identitário de cada grupo, localização e das modalidades faladas e escritas como questões necessárias ao falante.

Todo e qualquer ensino da Língua na concepção da educação linguística discute e reflete os padrões ideais, reais e linguísticos. Ensinar Língua em uma visão ampla que considere os contextos pressupõe-se entender como os sujeitos inter-relacionam-se com as práticas e as abordagens que se efetivam na produção-aquisição das experiências individuais e coletivas de compreensão da Língua; é ainda, entender que os propósitos sociocognitivistas produzem o esboço da educação linguística na concepção das práticas inclusivas.

Quando se pensa no ensino de Língua, há que se repensar também que todos devem ter as mesmas oportunidades de acesso ao conhecimento. Estudar, analisar e observar como a Língua se mantém e como fortalece os processos interativos vai além da mera concepção de que existam grupos eleitos e privilegiados, assim, alguns questionamentos surgem de imediato na circulação desta reflexão: como pensar a educação linguística na perspectiva da Educação Inclusiva? Quais são os recursos que tornam acessíveis aos sujeitos com limitações cognitivas, motoras, visuais e auditivas transitarem os mesmos caminhos que as pessoas sem deficiência? O que deve ser privilegiado? Como promover a educação linguística inclusiva?

A oralidade e a escrita pressupõem que o professor reflita constantemente acerca de seus paradigmas, bem como das adaptações necessárias pensadas na inclusão de todos. Além disso, leva-los a trilharem um percurso na construção de uma aprendizagem epilinguística é o que lhes possibilitará a operacionalização da própria linguagem, comparando, transformando ou, ainda, experimentando novas maneiras de construção, e que não sejam capazes apenas de reproduzir discursos, mas de escrever os próprios (SOUSA, 2016, p. 10).

A primeira visão que se deve ter é como a escola regular e suas práticas são pensadas na perspectiva da inclusão, como as normas, regras, rituais, metodologias, ações, diretrizes e orientações curriculares são empregadas na promoção do ensino e da aprendizagem de maneira igualitária, porque a escola inclusiva é o espaço de escolarização e de interação social no qual todos aprendem segundo suas aspirações, habilidades e necessidades, visto que no ambiente das metodologias e atitudes acessíveis as "identidades são transitórias, instáveis, inacabadas e, portanto, os alunos não são categorizáveis, não podem ser reunidos e fixados em categorias, grupos, conjuntos, que se definem por certas características arbitrariamente escolhidas" (ROPOLI et al, 2010, p. 07).

Linguagens \& Cidadania, v. 19, jan./dez., 2017. 


\section{S Linguagens}

Muitos são os recursos disponíveis para a promoção da educação linguística na perspectiva da inclusão escolar, assim sendo, no âmbito do ensino inclusivo há a necessidade de adequação do planejamento, de modo que potencialize as habilidades esperadas para o desenvolvimento dos sujeitos que por alguma questão se sentem impossibilitados de acessar o conhecimento de maneira igualitária, mesmo que para isso os professores tenham a ousadia de repensar como as propostas de ensino-aprendizagem são realizadas na perspectiva social e histórica da formação de sujeitos capazes de descortinar horizontes promissores no processo de escolarização.

Os professores constroem a democracia no cotidiano por meio de pequenos detalhes da organização da prática pedagógica. Nesse sentido, fazem a diferença: o modo de trabalhar os conteúdos com os alunos; a forma de sugerir a realização de atividades em sala de aula; o controle disciplinar; a interação dos alunos nas tarefas escolares (SANTOS, 2010, p. 13).

Considerar a efetivação da educação linguística no contexto da escola inclusiva é valorizar o conhecimento do uso da Língua que o sujeito faz no processo interativo e das concepções linguísticas, dos contextos e modos que cada um traz consigo. Assim, as práticas escolares adequam-se às necessidades dos falantes que chegam à escola com o anseio de organização dos conhecimentos inerentes à Língua Materna e à formação ética do cidadão.

Educar linguisticamente os sujeitos é entender como eles interagem com as propostas comunicativas e sociais, o que implica na valorização dos saberes e das maneiras que os indivíduos se relacionam com as ações de linguagem. É, ainda, saber que todos nós apresentamos individualidades que se coadunam na coletividade do ambiente acadêmico, na valorização da linguística na escola e no processo de formação entendido como práticas sociais dos indivíduos na complementação das culturas diferenciadas em que cada característica linguística se efetiva. De tal modo, a compreensão que o sujeito e os proponentes supõem da educação linguística é que são as ações e os saberes que "cada falante sabe, mas não sabe que sabe. É que qualquer pessoa tem conhecimento amplo e fundo da língua (ou das línguas) que ela fala” (BAGNO, 2014, p. 61, grifos do autor).

De tal modo ninguém conhece mais as necessidades linguísticas e acessíveis que as pessoas com limitação especial, porque sentem cotidianamente essa carência. Com a finalidade de destacar a necessária ausência da compreensão da educação linguística inserida 


\section{S Linguagens}

na proposta inclusiva, as reflexões ampliam-se e partem do seguinte questionamento: como propor uma educação linguística eficaz na escola inclusiva, valorizando as peculiaridades e a diversidade de cada sujeito? Uma das possíveis respostas é enxergar as individualidades em um processo amplo de formação em que sejam vistas as habilidades possíveis que podem ser desenvolvidas e não às limitações dos falantes.

\footnotetext{
Um ensino para todos os alunos há que se distinguir pela qualidade. O desafio de fazê-lo acontecer nas salas de aulas é uma tarefa a ser assumida por todos os que compõem um sistema educacional. Um ensino de qualidade provém de iniciativas que envolvem professores, gestores, especialistas, pais e alunos e outros profissionais que compõem uma rede educacional em torno de uma proposta que é comum a todas as escolas e que, ao mesmo tempo, é construída por cada uma delas, segundo as suas peculiaridades (ROPOLI et al, 2010, p. 10).
}

A oferta da educação linguística fortalece-se na qualidade destinada às práticas de ensino-aprendizagem e na valorização dos contextos sociais nos quais os sujeitos estão arraigados considerando o ensino da Língua na norma padrão e suas adaptações aos propósitos de cada indivíduo. Nesse sentido, a efetivação do processo da formação linguística de todos os alunos se coaduna em uma vertente interdisciplinar, cabendo não apenas ao professor de Língua Portuguesa discutir e valorizar os anseios dos sujeitos, mas de todos os educadores que têm o diálogo como ponte de acessibilidade ao conhecimento.

$\mathrm{Na}$ proposta da Educação Inclusiva, a educação linguística se efetiva pela interdisciplinaridade que se evidencia nas aprendizagens discentes, reflete como o conceito de norma é revistado e fortalecido nos usos e nos domínios das ciências da linguagem, já que todos nós somos partes desse grande processo linguístico e isso nos torna integrantes de uma ampla engrenagem que é a compreensão das finalidades habilitáveis linguísticas na formação dos discentes em uma visão acessível. Assim sendo, a proposição eficaz da educação linguística investiga e compreende o sistema fonológico de cada falante na função simbólica cultural e de acesso ao repertório linguístico.

A inclusão à luz da educação linguística compreende as peculiaridades locais, regionais e nacionais na compreensão de que o sujeito-aluno tem da Língua, da sua identidade e adaptações aos contextos sociais e de interação. De modo igual, a proposição das práticas de ensino-aprendizagem linguística tem a objetividade de descrever, valorizar e abordar a Língua nas suas variantes, ao mesmo tempo em que analisa os padrões valorizados pela escola e 


\title{
S Linguagens
}

desmitifique a politização de que uma única forma que se sobressaia, daí a necessidade de propor reflexões direcionadas à educação linguística nas práticas acessíveis de ensino, já que educar linguisticamente se insere no trabalho pedagógico das normas existentes em torno da Língua.

\begin{abstract}
Assim, a expressão norma culta deve ser entendida como designando a norma linguística praticada, em determinadas situações (aqueles que envolvem certo grau de formalidade), por aqueles grupos sociais mais diretamente relacionados com a cultura escrita, em especial por aquela legitimada historicamente pelos grupos que controlam o poder social (FARACO, 2012, p. 37).
\end{abstract}

O sucesso das práticas educacionais na valorização dos aspectos e dos propósitos linguísticos na Educação Inclusiva implica na promoção acessível, discursiva, reflexiva e respeitosa dos usos da linguagem na concepção das habilidades que se desenvolvem na ampliação conceptiva e filosófica em uma dimensão política e social capaz de flexibilizar as práticas escolarizadas na valorização das ações cotidianas, no fortalecimento das propostas linguísticas, socioculturais e socioeducativas, na promoção leitora e produtiva da dinâmica dos textos.

Diante disso, todo e qualquer processo de ensino eficaz e valorativo das capacidades linguísticas se insere na variação dos protótipos de uso social como ações e "padrões de comportamento linguístico observáveis dentro de uma comunidade de fala e os formaliza analiticamente através de um sistema heterogêneo, constituído por unidades e regras variáveis" (LUCCHESI, 2012, p. 60).

A transformação da escola regular em espaço de inclusão efetiva-se mediante a concretização do processo de educação linguística acessível tanto pela leitura, pela escrita, pela reflexão, quanto pela discussão. Por isso, educar os alunos linguisticamente pressupõe partir da realidade e de textos capazes de dialogar com as necessidades dos sujeitos, ensinando-lhes a escrever na escola e além das práticas escolares na dimensão constitutiva de formação ética, humanitária e cidadã. Do mesmo modo, a produção de quaisquer narrativas considera o conhecimento na escolarização dos indivíduos em uma proposta intertextual.

Produzir um texto é uma atividade bastante complexa e pressupõe um sujeito não apenas atento às exigências, às necessidades e aos propósitos requeridos por seu contexto sócio-histórico e cultural, mas também capaz de realizar diversas ações e 


\section{Linguagens \& Cidadania}

projeções de natureza textual, discursiva e cognitiva, antes e no decorrer da elaboração textual (MARCUSCHI, 2010, p. 65).

A produção de texto na Educação Inclusiva se mantém pela consideração do contexto no qual os sujeitos estão inseridos, assim como precisa ser a educação linguística que não se valha apenas da descrição dos fatores constituintes da linguagem, porém, ensinar como os indivíduos prescrevem os propósitos linguísticos e como os utilizam. Nesse sentido, a proposta de educação linguística na concepção do ensino inclusivo não se baseia no binário entre certo e errado, como é considerado por boa parte dos manuais didáticos, é preciso propor outras reflexões e análises, isto é, enxergar a Língua com sua dinâmica, adaptação e finalidades.

A proposição da educação linguística é fortalecida pela dinâmica que a Língua se realiza nas interações sociais, visto que educar linguisticamente é construir contextos acessíveis e capazes de inserir os sujeitos nas habilidades de produção da linguagem. Não se omite com isso que a diversidade na qual a Língua se efetiva nos contextos sociais, mas na valorização do ensino e aprendizagem da língua padrão e na amostragem de suas variantes. Assim sendo, os desafios e as possibilidades de formação e de valorização da educação linguística dialogam na escola inclusiva e constituem-se na produção dos saberes dos falantes no efetivo valor dado às finalidades da Língua em seu processo dinâmico e heterogêneo.

\section{AS PROXIMIDADES ENTRE SUJEITOS, LINGUAGENS E TECNOLOGIAS}

A promoção da educação linguística na escola inclusiva não desconsidera o uso das tecnologias disponíveis que potencializam o processo aquisitivo da linguagem porque valorizar as marcas linguísticas dos sujeitos é destacar os contextos nos quais estão inseridos, de onde são oriundos e como a escola destaca suas aprendizagens. Nesse sentido, os recursos tecnológicos nas propostas de inclusão são entendidos como Tecnologias Assistivas, que são definidas como "serviços que têm a intencionalidade de auxiliar as pessoas com deficiência ou alguma limitação na realização de atividades cotidianas, na vida profissional e no lazer de maneira autônoma e independente" (SOUSA, 2015, p. 90).

Os recursos tecnológicos, neste tópico, serão apresentados como alternativas para a inserção dos sujeitos com necessidades educativas especiais no contexto de escolarização do Linguagens \& Cidadania, v. 19, jan./dez., 2017. 


\section{S Linguagens}

conhecimento: a escola. Todas as propostas devem ser repensadas de modo a possibilitar o envolvimento dos estudantes nas ações metodológicas de ensino-aprendizagem, assim, das tecnologias simples como a adaptação de uma atividade às propostas mais sofisticadas mediatizadas pelas Tecnologias Digitais de Informação e Comunicação (TDIC), a promoção da educação linguística na escola inclusiva pauta-se em um trabalho interdisciplinar entre as áreas do conhecimento capaz de diversificar o currículo de maneira funcional.

Um currículo não disciplinar implica um ensino sem as gavetas das disciplinas, em que se reconhece a multiplicidade das áreas do conhecimento e o trânsito livre entre elas. O ensino não disciplinar não dever ser confundido com os Temas Transversais dos Parâmetros Curriculares Nacionais, os quais não superam a disciplinarização, continuando a organizar o currículo em disciplinas, pelas quais perpassam assuntos de interesse social, como o meio ambiente, sexualidade, ética e outros (SANTOS, 2010, p. 16).

É preciso, pois, transversalizar as práticas de ensino e constituí-las em um processo dialógico entre as demais disciplinas do currículo. Esse diálogo possibilita que os estudantes transitem entre os campos do saber escolar e social capaz de construir pontes entre o conhecimento e os sujeitos inseridos nas situações de aprendizagem, contextualizando, reconhecendo e valorizando as experiências estudantis a partir das peculiaridades de cada um, inserido na coletividade da troca de conhecimento, na identificação e na organização das ações de acessibilidade.

Refletir as propostas de acessibilidade à educação linguística na vertente da Educação Inclusiva é, ao mesmo tempo, considerar o uso dos recursos de Tecnologias Assistivas. Essas tecnologias representam alternativas que permitem o acesso ao conhecimento no contexto escolar.

A primeira intervenção que pode amenizar algumas das barreiras vivenciadas pelos sujeitos com necessidades especiais, destina-se aos estudantes com o campo visual reduzido, chamados pela literatura especializada, de baixa visão ou visão subnormal, isto é, são os indivíduos que precisam ter ampliados os recursos de leituras e de escrita que podem ser utilizadas mediante o auxílio de recursos ópticos e não ópticos.

Assim, na concepção do aluno com baixa visão, algumas recomendações são essenciais para possibilitar a interação e a aprendizagem dele, tais como: iluminação adequada, contrastes nas formas e cores, ampliação de letras, desenhos e jogos, guia de 


\section{Singuagens}

leitura, o que se conhece por régua vazada, o uso de lápis $5 \mathrm{~B}$ ou $6 \mathrm{~B}$, visto que muitos estudantes com baixa visão só conseguem enxergar a escrita realizada com grafite de cor escura, canetas de pontas porosas e pincel atômico sempre nas cores: preta e azul-escuro, caderno com pauta ampliada, específico para o atendimento do alunado, além dos recursos mais sofisticados e tecnológicos que utilizam a informática para acessar o conhecimento e produzir suas convicções na ampla área do saber, porém, além de todas essas questões as atitudes do professor frente aos desafios são essenciais.

A ampliação de textos e imagens mediante a utilização dos recursos tecnológicos da informática pode ser realizada pela ferramenta Zoom, que é conseguida pelo aplicativo Word, mudando-se também o estilo da fonte e a tonalidade da letra, por exemplo, negritar os caracteres. Como se percebe são recomendações simples, mas que exigem estudo, pesquisa e conhecimento por parte do professor para que os estudantes tenham acesso à cultura letrada e, consequentemente, aos textos que lhes são oferecidos para que possam participar ativamente das discussões de sala de aula.

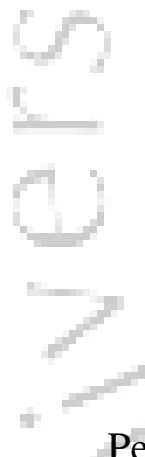

O monitor deve ser elevado à altura da linha mediana da visão. Monitores com no mínimo 17 polegadas e tela plana possibilitam melhor configuração. Em relação à proximidade, recomenda-se, à medida do possível, uma distância de $30 \mathrm{~cm}$, mas quando for necessária maior aproximação, deve-se usar o monitor por curtos períodos. O Suporte para Apoio de Textos Complementares pode ser fixado lateralmente ao computador ou colocado ao lado da mesa na altura desejada (DOMINGUES; CARVALHO; ARRUDA, 2010, p. 16).

Pequenas atitudes podem fazer toda a diferença na efetivação do processo de inclusão educativa e linguística dos estudantes no contexto escolar, visto que o processo inclusivo e de acessibilidade não depende, unicamente, das Tecnologias Assistivas e da infraestrutura do espaço, mas também da mudança atitudinal docente e propositiva na produção do conhecimento, adaptando os currículos e as práticas às necessidades estudantis e não os estudantes se adequarem às ações metodológicas.

Outro recurso que pode ser utilizado no contexto da educação linguística inclusiva é saber operacionalizar e conhecer as vantagens do Sistema Operacional Dosvox que oferece programas como "editor de texto, leitor de documentos, recurso para impressão e formatação de textos em tinta e em Braille. Contém jogos didáticos e lúdicos, calculadora vocal, 


\section{Singuagens}

programas sonoros para acesso à Internet, como correio eletrônico, acesso à homepages, telnet, FTP e chat" (DOMINGUES; CARVALHO; ARRUDA, 2010, p. 22).

O software Dosvox é um programa com síntese de voz e possibilita aos sujeitos com baixa visão e com cegueira ouvir a leitura de textos, além de outras possibilidades de efetivação da educação linguística. Cabe destacar que o Sistema Operacional Dosvox foi desenvolvido pelo Núcleo de Computação Eletrônica, da Universidade Federal do Rio de Janeiro (NCE/UFRJ) e pode ser realizado o download ${ }^{1}$ gratuitamente, bem como ser operacionalizado na escola.

Todo processo tecnológico se efetiva de uma proposta de acessibilidade e de inclusão dos sujeitos a determinados contextos e serviços: inclusão pela informação, pelo acesso à produção literária e formulação de novos conceitos, integrando indivíduo na sociedade, dando-lhe a oportunidade de adquirir os mesmos bens e serviços.

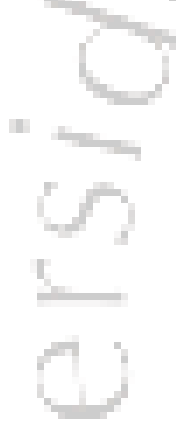

Os termos Acessibilidade e Tecnologia Assistiva são os pontos-chave da política de inclusão. À luz da sociedade inclusiva, a participação de todos deve acontecer de forma igualitária, na regalia dos mesmos direitos e no cumprimento dos deveres. Uma gestão para a inclusão se constrói e se fortalece a partir das políticas de acessibilidade vivenciadas na escola e estendidas as práticas sociais (SOUSA, 2015, p. 90).

Nesse sentido, na imagem abaixo, há uma representação da tela inicial do programa com síntese voz que pode ser utilizado na leitura e no acesso aos textos e aos demais recursos necessários na efetivação das aprendizagens no contexto escolar evidenciando a promoção da educação inclusiva linguística.

Figura 1: TELA INICIAL DO SISTEMA OPERACIONAL DOSVOX

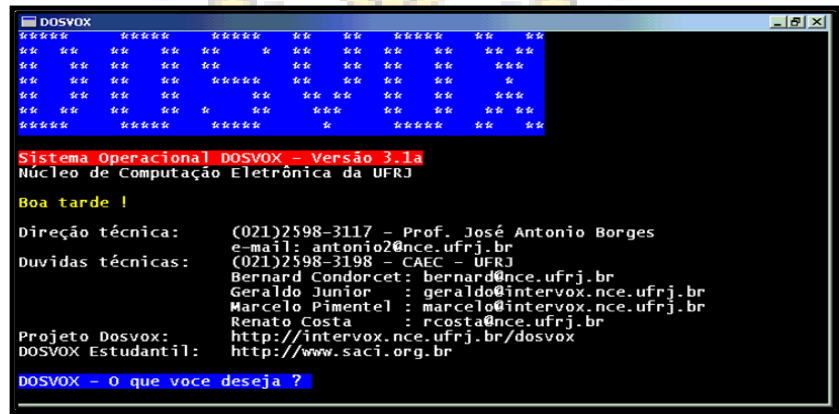

${ }^{1}$ O Sistema Operacional Dosvox está disponível para download em: <http://intervox.nce.ufrj.br/dosvox>.

Linguagens \& Cidadania, v. 19, jan./dez., 2017. 


\section{S Linguagens}

Além do Sistema Operacional Dosvox, outros programas como leitores de tela e recursos sonoros podem ser utilizados na ampliação das propostas de educação linguística na escola inclusiva, cabendo, pois, ao professor manter a flexibilidade no planejamento o que não basta apenas saber da existência desses recursos, mas, saber manuseá-los para que o aluno com necessidades educacionais especiais seja inserido no contexto de ensino.

É interessante, ainda, ao docente, o conhecimento de outros recursos tecnológicos, como os seguintes: deltatalk (que é um sintetizador de voz desenvolvido pela empresa Micropower), leitores de tela (programas que permitem a leitura, por meio de síntese de voz, de elementos e de informações textuais), Non Visual Desktop Access - NVDA (leitor de telas livre e gratuito, de código aberto, para o sistema operacional Windows), Virtual Vision (permite utilização do ambiente Windows, os aplicativos Office, navegação pela Internet, uso de programas de comunicação), Jaws (permite operar no ambiente Windows e em seus aplicativos, utilizar programas, editar documentos, ler páginas Web, criado pela empresa internacional Freedomscientific) e Orca (possibilita o acesso ao ambiente Linux e a suas ferramentas, sendo, portanto, um leitor de telas livre). Assim, todas as interfaces tecnológicas apresentadas podem ser acessadas gratuitamente para que se permitam aos sujeitos com necessidades o acesso à informação.

Ensinar no contexto da inclusão é entender o espaço escolar aberto à criatividade metodológica considerando as necessidades e as peculiaridades de cada estudante. Além dos recursos midiáticos supracitados, há, ainda, o Daisy (Digital Acessible Information System), desenvolvido pelo consórcio Daisy em 1996, nos Estados Unidos com a função de produzir livros acessíveis, além de representar mais uma alternativa para o trabalho escolarizado na perspectiva da educação linguística no espaço inclusivo escolar.

No Brasil, o software Mecdaisy originou-se a partir de uma parceria entre o Núcleo de Computação Eletrônica da Universidade Federal do Rio de Janeiro e o Ministério da Educação e Cultura (MEC), de modo a auxiliar a leitura de livros, revistas e artigos ou quaisquer formas textuais às pessoas com limitação visual, assim como os demais visam a ampliação da política de inclusão nos ambientes escolares e sociais. O manuseio do Mecdaisy faz-se mediante os seguintes propósitos: ir diretamente para determinada página, fazer anotações no livro, marcar um determinado trecho, navegar pelo índice do livro e ir direto a um capítulo ou seção.

Linguagens \& Cidadania, v. 19, jan./dez., 2017. 


\section{S Linguagens}

O Projeto Mecdaisy é também um sintetizador de voz e permite aos estudantes utilizarem em consonância com a política do Programa Nacional do Livro Didático (PNLD), sendo, pois, um software livre que cumpre a função de amenizar as barreiras da informação às pessoas com necessidades educativas especiais.

Figura 2: SOFTWARE MECDAISY

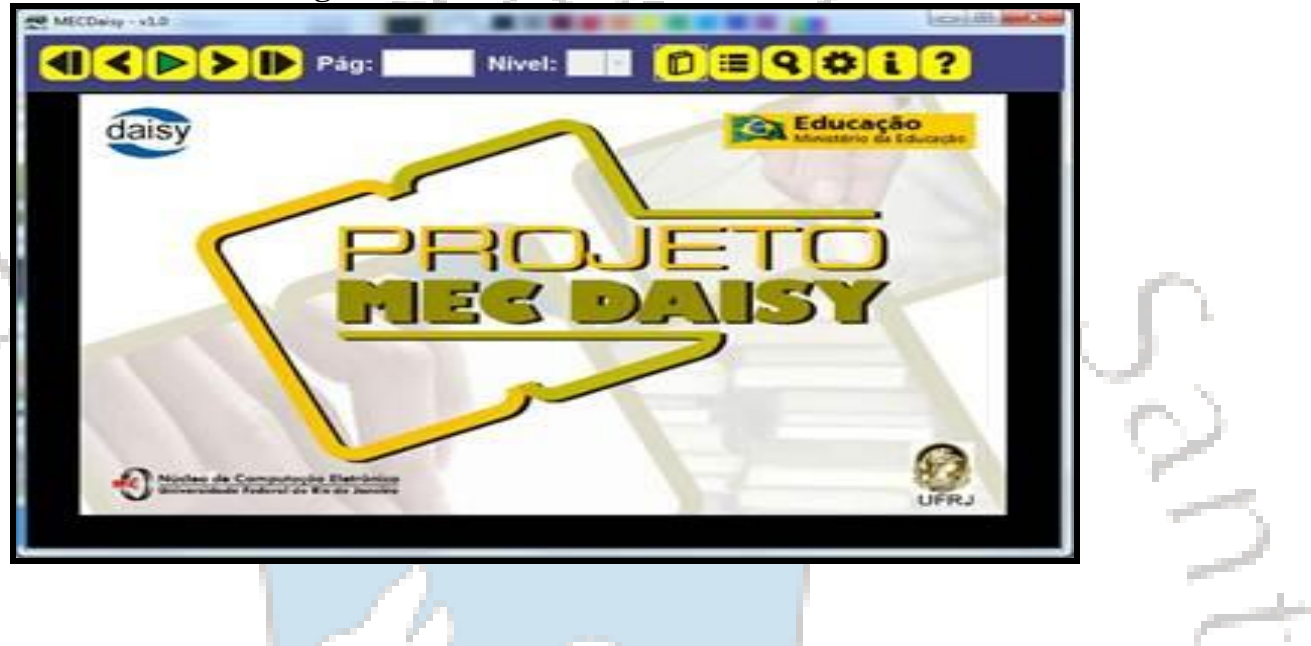

Os propósitos de todos os recursos tecnológicos apresentados, doravante, enquadramse nas ações e na política da Educação Especial na perspectiva da Educação Inclusiva e de acessibilidade ao conhecimento, sendo, pois, propostas de tecnologia assistiva. Essa classificação tecnológica identifica todo o "arsenal de recursos e serviços que contribuem para proporcionar ou ampliar habilidades funcionais das pessoas com deficiência e, consequentemente, promover vida independente e inclusão" (SCHIRMER et al, 2007, p. 31).

Muitas são as questões que devem ser visualizadas na escola quando se projeta o acesso à educação linguística inclusiva. É preciso considerar que a diversidade dos estudantes é que torna as práticas metodológicas flexíveis e, ao mesmo tempo, dinâmicas. Não há como esquecer que são várias as necessidades educacionais especiais dos sujeitos que buscam na instituição escolar uma oportunidade de se inserirem socialmente no contexto das aprendizagens, assim, os estudantes que compõem a Comunidade Surda precisam também ser vistos, ouvidos e atendidos nas suas limitações linguísticas possibilitando que o espaço escolar se torne um local bilíngue, de respeito e sem a caracterização dos estereótipos estabelecidos socialmente.

Linguagens \& Cidadania, v. 19, jan./dez., 2017. 


\section{$\checkmark$ Linguagens}

É nesse sentido que o aplicativo Hand Talk App se configura como uma das possibilidades de interação e comunicação entre a Comunidade Surda e ouvintes, visto que as tecnologias estão cada vez mais presentes nos interiores das salas de aula. Assim sendo, o aplicativo permite que haja a tradução da Língua Portuguesa, segunda língua (L2) para a primeira língua (L1), Língua Brasileira de Sinais para o surdo por intermédio da tecnologia, fortalecendo com isso, a ampliação da educação linguística na escola de todos e para todos.

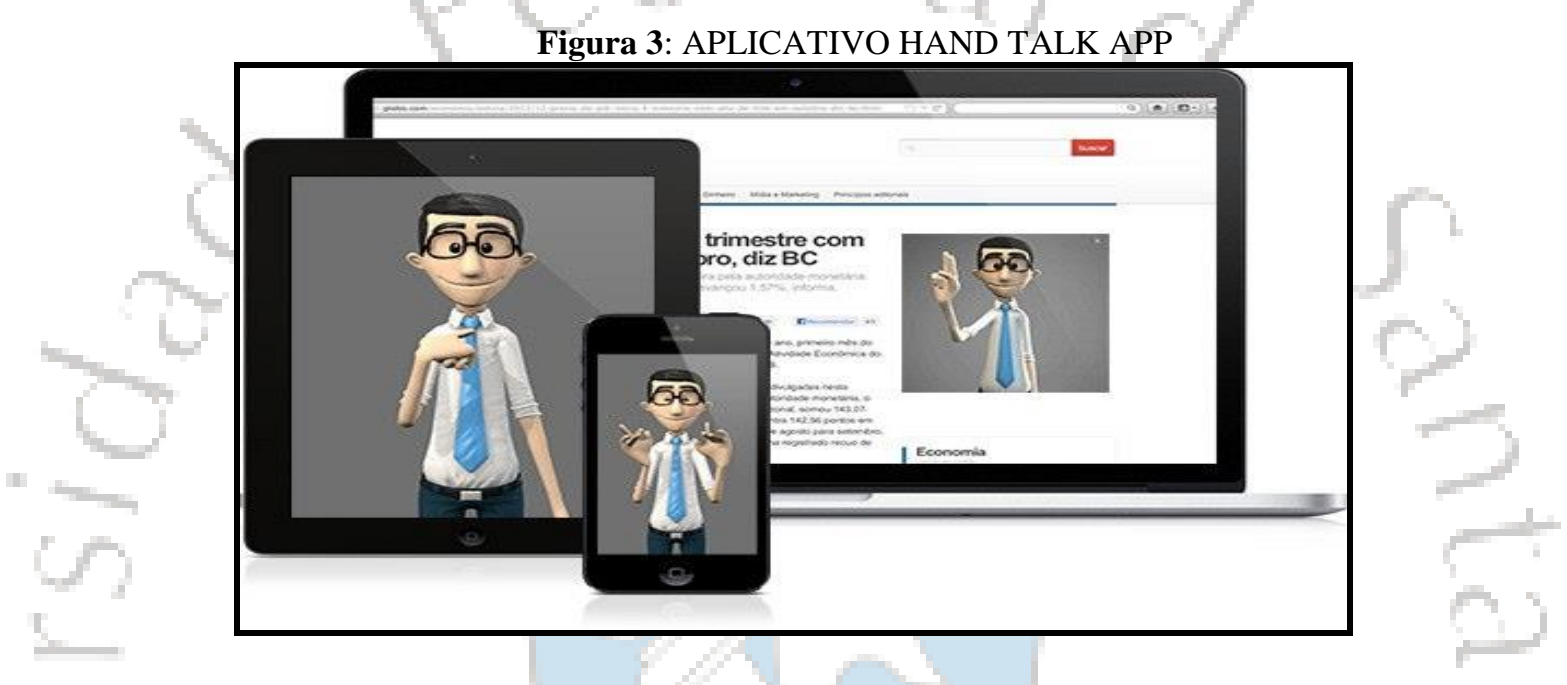

Reafirma-se que a função do aplicativo Hand Talk App não é a substituição do profissional intérprete e do tradutor da Língua Brasileira de Sinais, porém, cumpre a função de oferecer alternativas para que o processo comunicativo entre surdos e ouvintes seja fortalecido no contexto da escola inclusiva inserido na proposta de educação linguística. Ora, a educação linguística é, exatamente, a valorização do contexto e da maneira como os sujeitos se relacionam com a Língua na modalidade escrita e falada, tendo como referência a valorização das marcas identitárias que se inserem na formação de cada indivíduo, oferecendo-lhe oportunidades de contextualização das teorias linguísticas que circulam no espaço acadêmico e sua relatividade com as transformações sociais.

Na perspectiva da educação linguística não há uma maneira correta ou errada de falar, mas, sim, variantes que possibilitam aos falantes se expressarem, demonstrando suas raízes identitárias e intelectuais que se socializam na interação com outras culturas, visto que é na dinamicidade que a Língua se realiza e se fortalece. Assim, o conceito de certo ou errado na promoção de uma educação linguística inclusiva não tem espaço, o que ganha destaque é a 


\section{S Linguagens}

valorização e o acolhimento de outras formas de representar o pensamento porque enxerga o ser humano e suas condições de acesso às práticas de ensino e de experiência com a linguagem.

O ensino do português muitas vezes difunde a crença de que existe uma maneira "certa" de usar a língua, e que essa é a única maneira aceitável; todas as outras são "erradas", devem ser evitadas. Isso é reforçado por colunas em jornais, gramaticas escolares, livros de "não erre mais" e a pressão social de todo momento. Essa atitude, com suas perniciosas consequências, tem sido objeto de crítica por parte de linguistas e professores, mas continua muito presente na escola e na vida (PERINI, 2006, p. 21, grifos do autor).

Toda forma de ensinar é, ao mesmo tempo, tradicional e inovadora. Tradicional quando não considera as reais necessidades que os falantes apresentam no processo comunicativo e inovador quando amplia e demonstra que as chances de acesso ao conhecimento podem ser realizadas de diferentes maneiras e formas, de modos e sentidos múltiplos. Torna-se dinâmica quando permite aos sujeitos conhecerem, verdadeiramente, a Língua em todas as suas nuances no direcionamento cabível da concretização da educação linguística.

De modo igual, propor o ensino de Língua na concepção da escola inclusiva é dialogar com as vantagens que as transformações sociais e tecnológicas atribuem ao processo de reflexão, ensino e aprendizagem dos significados da Língua capaz de direcionar os falantes na valorização e na construção de significados que estão inseridos na experiência de cada um, que todas as Línguas, na concepção linguística, apresentam uma estrutura própria e efetiva-se no dinamismo dos efeitos intencionais da comunicação, já que é na interação social que os propósitos linguísticos tomam forma e sentidos, porque educar linguisticamente é saber garimpar entre os textos que nos são oferecidos as marcas de intertextualidade com outras áreas do conhecimento propondo a certeza de que o ensino linguístico eficaz se concretiza na função interdisciplinar que a Língua assume no seu caráter heterogênico e multifacetado.

\section{CONSIDERAÇÕES FINAIS}

Refletir como a Língua se realiza e cumpre sua função social é enveredar por um caminho minado de desafios, mas também, ao mesmo tempo, de possibilidades. Talvez essa 


\section{S Linguagens}

seja a sensação que todos os sujeitos que vislumbram na escola a chance de mudar suas trajetórias se fortalecem no conceito de que é possível a construção de um ensino, de práticas metodológicas e tecnológicas utilizadas na aquisição e na ampliação das capacidades linguísticas na formação de pessoas que não apenas reproduzem os discursos produzidos, mas que saibam respeitar as pesquisas realizadas e projetar novas e dinâmicas formas de dizer.

É nesse sentido que a educação linguística se encontra, isto é, no contexto das oportunidades, inserida em um contínuo processo de buscas, reflexões e produção compreensível das modalidades que a Língua assume na formação do cidadão, visto que todo processo de trabalho com a linguagem se constitui em uma vertente da interface do letramento escolarizado e social no qual os sujeitos são apresentados permitindo-lhes que ampliem seus processos de aquisição do repertório linguístico cultural.

Entender e saber como a educação linguística realiza-se na escola das possibilidades de aprendizagem e de produção do conhecimento implica na valorização da história e do percurso linguístico que cada falante faz para interagir com seus semelhantes, além disso, a educação linguística inclusiva enxerga nos recursos tecnológicos a oportunidade de permitir que todos tenham os mesmos acessos, direitos e deveres na elaboração do contexto sociolinguístico que nos torna únicos, mas que se realiza na coletividade humana.

A educação linguística é uma representação da política de inclusão nos interiores das instituições escolares e na sociedade, pois não há uma única forma que pode ser considerada correta e que marginalize as outras que não estejam adequadas ao propósito comunicativo. $\mathrm{O}$ exercício linguístico de reconhecimento das peculiaridades que o outro traz para a comunicação é o que torna a compreensão e a relação humana um projeto social e linguístico de sociedade inclusiva, tendo as vantagens que as tecnologias digitais de informação e comunicação propõem no acesso às práticas de produção do conhecimento e de compreensão da Língua. Dessa forma, a abordagem da educação linguística na Educação Inclusiva encontra nas Tecnologias Assistivas espaço para rediscutir e inserir os estudantes com necessidades educacionais especiais nas ações metodológicas, pois a politização da educação linguística inclusiva precisa assumir funções dinâmicas, adaptáveis, acessíveis e heterogêneas como ocorre com a compreensão que os falantes devem ter da língua.

Linguagens \& Cidadania, v. 19, jan./dez., 2017. 


\section{Singuagens}

\section{REFERÊNCIAS BIBLIOGRÁFICAS}

BAGNO, M. Língua, linguagem, linguística: pondo os pingos nos ii. São Paulo: Parábola Editorial, 2014.

DOMINGUES, C. dos A.; CARVALHO, S. H. R.; ARRUDA, S. M. C. de P. Características da baixa visão. In: DOMINGUES, C. dos A. et al. A Educação Especial na perspectiva da Inclusão Escolar: os alunos com deficiência visual - baixa visão e cegueira. Brasília: Ministério da Educação, Secretaria de Educação Especial; [Fortaleza]: Universidade Federal do Ceará, 2010.

FARACO, C. A. Norma-padrão brasileira: desembaraçando alguns nós. In: BAGNO, M. (Org.). Linguística da norma. $3^{a}$ ed. São Paulo: Edições Loyola, 2012.

LUCCHESI, D. Norma linguística e realidade social. In: BAGNO, M. (Org.). Linguística da norma. $3^{\mathrm{a}}$ ed. São Paulo: Edições Loyola, 2012.

MARCUSCHI, B. Escrevendo na escola para a vida. In: RANGEL, E. de O.; ROJO, R. H. R. (Orgs.). Língua portuguesa: ensino fundamental. Brasília: Ministério da Educação, Secretaria de Educação Básica, 2010.

MARCUSCHI, L. A. Linguística de texto: o que é e como se faz? São Paulo: Parábola Editorial, 2012.

PERINI, M. A. Princípios de linguística descritiva: introdução ao pensamento gramatical. São Paulo: Parábola Editorial, 2006.

RODRIGUES, A. D. Problemas relativos à descrição do português contemporâneo como língua padrão no Brasil. In: BAGNO, M. (Org.). Linguística da norma. $3^{\mathrm{a}}$ ed. São Paulo: Edições Loyola, 2012.

ROPOLI, E. A. et al. A Educação Especial na perspectiva da inclusão escolar: a escola comum inclusiva. Brasília: Ministério da Educação, Secretaria de Educação Especial; [Fortaleza]: Universidade Federal do Ceará, 2010.

SANTOS, M. T. da C. T. O Projeto Político Pedagógico, autonomia e gestão democrática. In: ROPOLI, E. A. et al. A Educação Especial na perspectiva da inclusão escolar: a escola comum inclusiva. Brasília: Ministério da Educação, Secretaria de Educação Especial; [Fortaleza]: Universidade Federal do Ceará, 2010.

SCHIRMER, C. R. [et al]. Atendimento Educacional Especializado: deficiência física. Brasília - DF: Cromos, 2007.

SOUSA, I. V. Tecnologia acessível: reflexões sobre a utilização de recursos tecnológicos sonoros como acessibilidade aos textos literários para o aprendiz com deficiência visual. In:

Linguagens \& Cidadania, v. 19, jan./dez., 2017. 


\section{S Linguagens}

Desafios: Revista interdisciplinar da Universidade Federal do Tocantins. v. 01, n. 02, p. 84-103, jan/jun. 2015. Disponível em:

$<$ https://sistemas.uft.edu.br/periodicos/index.php/desafios/article/view/925>. Acesso em: 15 mar. 2017.

Os gêneros textuais orais e escritos na Educação de Jovens e Adultos. In: Ribanceira: Revista do curso de Letras da Universidade do Estado do Pará (UEPA). Belém, volume. VI, número 01, jan/jun. 2016. Disponível em: <

https://paginas.uepa.br/seer/index.php/ribanceira/article/view/882>. Acesso em: 15 mar. 2017.

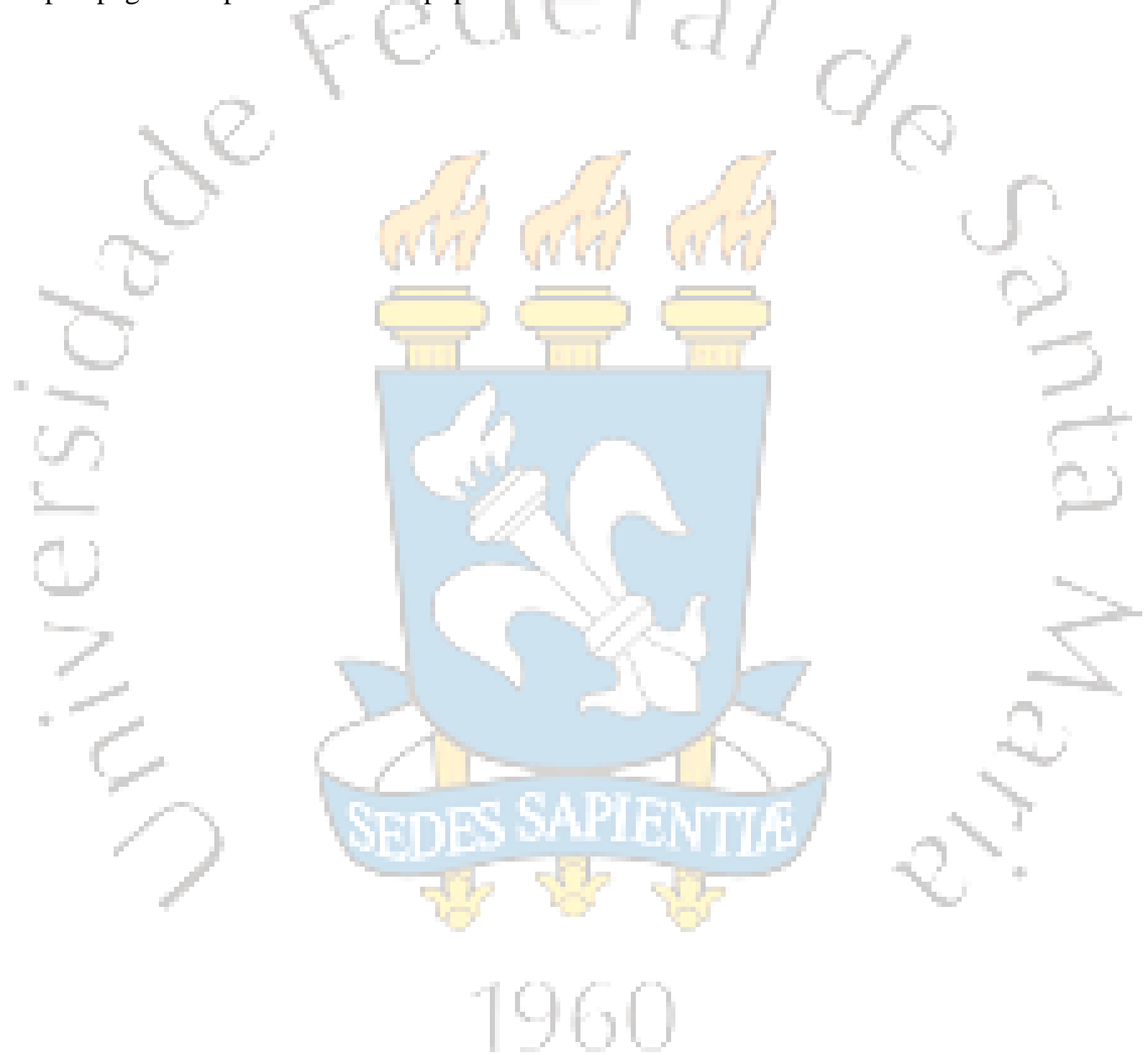

Linguagens \& Cidadania, v. 19, jan./dez., 2017. 